\section{Reducing Water and Pesticide Movement in Nursery Production}

\author{
Damon E. Abdi and R. Thomas Fernandez ${ }^{1}$
}

AdDitional INDEX wORDs. agrochemical, container production, effluent, infiltration, irrigation, runoff

SUMMARY. Ornamental nurseries produce a large number of plants in a concentrated area, and aesthetics are a key component of the product. To produce crops in this manner, high inputs of water, nutrients, and pesticides are typically used. Container nursery production further increases the inputs, especially water, because container substrates are designed to quickly drain, and the most effective method of irrigating large numbers of plants in containers (up to a certain size) is the use of overhead irrigation. Because irrigation and pesticides are broadcast over the crop, and because the crop is limited to the container, a large proportion of water or pesticides may land on nontarget areas, creating runoff contaminant issues. Water is the primary means of pesticide movement in nursery production. This review discusses water and pesticide dynamics and management strategies to conserve water and reduce pesticide and water movement during container nursery production.

$\mathrm{C}$ ontainer nursery crop production is an input-intensive industry with respect to water and agrochemical use, and daily irrigation, high fertilizer rates, and multiple applications of pesticides throughout the season are common practices (Agro and Zheng, 2014; Briggs et al., 2003; Dennis et al., 2010; Mangiafico et al., 2008; Riley, 2003; Wilson et al., 1995). Runoff water generated from irrigation or precipitation events can move agrochemicals out of the production area, exporting deleterious quantities of nutrients and pesticides to surface waters or on-site retention ponds ( $\mathrm{Lu}$ et al., 2006; Warsaw et al., 2009b, 2012). Efforts to reduce the movement of

$\overline{\text { Received for publication l Feb. 2019. Accepted for }}$ publication 27 Mar. 2019.

Published online 5 August 2019

Department of Horticulture, 1066 Bogue Street, Room A2 16, Michigan State University, East Lansing, MI 48824-1325

This material is based on work supported by the National Institute of Food and Agriculture, U.S. Department of Agriculture under award number 2014-51181-22372, and Hatch project number MICL 02473.

This paper is based on information presented during the Clean WateR3 program sessions held as part of the ASHS Annual Conference, 30 July to 3 Aug. 2018 in Washington, DC.

${ }^{1}$ Corresponding author. E-mail: fernan15@msu.edu.

This is an open access article distributed under the CC BY-NC-ND license (https://creativecommons.org/ licenses/by-nc-nd/4.0/).

https://doi.org/10.21273/HORTTECH04298-19 pesticides can be realized through improved irrigation practices, nursery infrastructure designs, pesticide application methods, and pesticide selection based on chemical properties (Chappell et al., 2013; Mahnken et al., 1999; Majsztrik et al., 2017; Wilson et al., 1996).

\section{Irrigation method and scheduling}

Irrigation in the nursery is often applied daily using overhead impact sprinklers (Beeson and Knox, 1991; Fulcher and Fernandez, 2013a; Paudel et al., 2016). Overhead irrigation provides water to the entire nursery production surface-the containerized plants and the intercontainer spaces; however, the majority of water applied using overhead irrigation fails to reach the crop, with $74 \%$ to $87 \%$ landing in the intercontainer spaces, where it may contribute to surface runoff or infiltrate the production surface (Ross et al., 2001; Weatherspoon and Harrell, 1980). The canopy architecture of container-grown plants as well as the spacing between containers influences water movement, potentially capturing more water within the container or shedding it outside (Davies et al., 2016; Million et al., 2005). Nurseries irrigating with overhead systems will typically apply between 0.3 and 1.3 inches of water each day, thus necessitating an ample supply of water being available throughout the season (Fulcher and Fernandez, 2013a). Alternatively, microirrigation can be used for nursery production to provide water directly to plants, thereby increasing the application efficiency (Mathers et al., 2005). Generally, investments in microirrigation are reserved for the production of crops grown in larger containers (19 L or larger), where the plant canopy may undesirably intercept and redistribute overhead irrigation (Beeson and Knox, 1991; Majsztrik et al., 2017). Microirrigation methods such as individual container spray stakes require less water than overhead irrigation; however, although more efficient at applying, microirrigation systems demand higher-quality water and routine monitoring to ensure that emitters are not clogging and that all plants are receiving water, which is a less intensive consideration when using overhead irrigation (Owen et al., 2016).

Irrigation is preferentially applied in the morning during periods of low winds, when evapotranspiration is lowest (Fulcher and Fernandez, 2013a, 2013b). The volume of irrigation water applied can be reduced through irrigating to replace the crop daily water use and/or the use of cyclic applications (Karam and Niemiera, 1994; Pershey et al., 2015; Warsaw et al., 2009a, 2009b). Splitting a single, continuous irrigation event into cyclic applications may allow substrates to hydrate more evenly and reduce preferential channeling through the container substrate, particularly in dry substrates (Hoskins et al., 2014; Taylor et al., 2013). Substrate moisture sensors quantify water content within containers and may be used to make more informed irrigation decisions when controlled manually or as part of an automated irrigation control system

\begin{tabular}{llll}
\hline $\begin{array}{l}\text { Units } \\
\begin{array}{l}\text { To convert U.S. to SI, } \\
\text { multiply by }\end{array}\end{array}$ & U.S. unit & SI unit & $\begin{array}{l}\text { To convert SI to U.S., } \\
\text { multiply by }\end{array}$ \\
\hline 3.7854 & gal & L & 0.2642 \\
25.4 & inch(es) & $\mathrm{mm}$ & 0.0394
\end{tabular}


(Lea-Cox et al., 2013; Pershey et al., 2015). Crop quality may be improved through irrigating to meet substrate moisture thresholds, and it can be used to influence root/shoot growth, plant size, and flowering (Bayer et al., 2015; Pershey et al., 2015; Warsaw et al., 2009a, 2009b). Irrigating using sensor-controlled irrigation systems reduced the instances of water-borne pathogen mortality in gardenia [Gardenia augusta 'MADGA l' (Heaven Scent $\left.{ }^{\mathrm{TM}}\right)$ ] production, and it decreased the time necessary to produce a salable crop, thereby increasing operation profitability by reducing input expenses and increasing crop production and leading to a $116 \%$ increase in annual profit relative to previous practices (Lichtenberg et al., 2013). Reducing water use provides economic benefits; however, modifying irrigation practices may not be fiscally motivating because increasing regulatory pressure may also guide decision-making (Bolques et al., 2011; Fulcher et al., 2016; Lea-Cox and Ross, 2001).

\section{Runoff generation}

The amount of water applied in nurseries contributes to nursery runoff, with increasing application rates resulting in greater volumes of runoff water (Fulcher and Fernandez, 2013b; Pershey et al., 2015; Warsaw et al., 2009a, 2009b). Reducing the volume of runoff generated can be accomplished through irrigating based on plant water use (Bayer et al., 2015; Pershey et al., 2015; Warsaw et al., 2009b). Surface runoff can facilitate the movement of agrochemicals, either in the dissolved phase or in a bound particulate phase; however, water infiltrating through the soil has the potential to transport dissolved compounds through soils. Substantial volumes of runoff are generated from irrigation falling between containers, precipitation, and container leachate, thus contributing to the removal of nutrients and pesticides from production areas. Agrochemical loss from container nursery production poses an environmental threat because recycled irrigation water at phytotoxic concentrations may be deleterious to crops (Mahnken et al., 1999). Concerns regarding the level of contamination present in runoff water can be mitigated through using best management practices (BMPs), such as installing buffer zones and improving water/ chemical application practices; however, additional treatments to remove pesticide residues may be necessary before environmental discharge or use as recycled irrigation water (Grant et al., 2019; Lu et al., 2006). The implementation of treatment systems to address agrochemical content in runoff water requires a financial investment in an associated infrastructure, encouraging the use of these systems for recycling irrigation water to capitalize on the investment (Pitton et al., 2018).

\section{Nursery production surface and infrastructure}

Nursery production sites should be constructed to facilitate the movement of runoff water to desired locations as part of a larger water infrastructure system (Majsztrik et al., 2011). The slope and material used for constructing the production surface impact the movement of water and associated agrochemicals, erosion of soil/organic matter and adsorbed compounds, as well as weed presence (Million et al., 2005; Wilson et al., 1995). Groundcover surfaces common in nursery production include plastics, landscape fabric, and uncovered porous aggregate, each of which are capable of generating substantial amounts of runoff water and of influencing agrochemical export (Briggs et al., 2002). Although the authors did not compare water runoff or infiltration due to groundcover, it is likely that different groundcovers will result in different partitioning of water effluent to runoff or infiltration. Contaminant and sediment contents in runoff or infiltration water can be addressed through the implementation of BMPs, such as installing sedimentation basins, phytoremediation areas, filter socks, and vegetated filter strips, for the interception of contaminated water as it exits production areas and before discharge to the environmental or on-site retention (Briggs et al., 1998; Fulcher and Fernandez, 2013b; Majsztrik and LeaCox, 2013; Majsztrik et al., 2017; Shipitalo et al., 2010; Spangler et al., 2019; Warsaw et al., 2012). Because many pesticides exhibit a tendency to adsorb to soils and other suspended particles in runoff water, facilitating the settling of sediments can reduce the movement of certain compounds. The design of sediment-reducing treatments should consider the maintenance and management of these systems, particularly regarding periodic removal of sequestered sediments.

\section{Pesticide properties}

The fate of a pesticide is influenced by its inherent chemical properties, with the mobility of a compound dependent on how it is partitioned within the nursery and the environment at large. Pesticides exhibit a range of chemical properties between and within chemical classes, with solubility in water, adsorption coefficients, and vapor pressure of a particular compound suggesting the likely fate (Langeron et al., 2014). Pesticide movement in runoff water can occur with the pesticide either dissolved in water or transported and adsorbed on soil particles/organic matter (Boithias et al., 2014; Lao et al., 2008). Soils, particularly clay and organic matter fractions, serve as adsorption sites for pesticides, with the clay fraction critical to the adsorption of polar pesticides and organic matter (particularly organic carbon) providing the nonionic sorption sites for lipophilic pesticides (Dion et al., 2001; Mantzos et al., 2014). Partition coefficients indicate the likelihood of a compound to bind or adsorb to soils $\left[\mathrm{K}_{\mathrm{d}}\right.$ (concentration of the chemical in soil/ concentration of the chemical in water)], the organic material portion within soils $\left[\mathrm{K}_{\mathrm{om}}\right.$ (concentration of the chemical in organic matter/concentration of the chemical in water)], and, specifically, the organic carbon fraction of soils $\left[\mathrm{K}_{\mathrm{oc}}\left(\mathrm{K}_{\mathrm{d}} \times 100 / \%\right.\right.$ of organic carbon)] (Bedos et al., 2002). Plastics are capable of adsorbing certain pesticides, particularly nonionic compounds, and the partition coefficient $\mathrm{K}_{\mathrm{pw}}$ (concentration of chemical in a plastic polymer/concentration of chemical in water) may be used to measure the sorption of a pesticide with various plastic polymer chemistries (Lee et al., 2014; O'Connor et al., 2016). Unfortunately, $\mathrm{K}_{\mathrm{pw}}$ is not available for most pesticides, and sorption may vary with different polymer compositions. Adsorption and desorption are constantly occurring. The adsorption coefficients provide an indication of the strength with 
which compounds are bound to various substrates individually at equilibrium. In a natural setting where equilibrium is unlikely and many compounds are present, a particular pesticide may be adsorbed in one area of an operation, such as the production surface, and transported to another area, such as a reservoir, where it is desorbed and replaced on the binding site by a different compound.

Pesticides will also partition between phases, with Henry's Law constant indicating the likelihood of a pesticide volatilizing into the air or remaining within water. This coefficient, calculated as a particular compound vapor pressure divided by solubility, provides an indication of the likely partitioning between water or the atmosphere, with a greater value indicating that volatilization is more likely to occur (Suntio et al., 1988). The length of time for which a particular contaminant may be present in a given environment can be estimated through half-life (the amount of time required for half of a given compound to degrade) measurements (Hanson et al., 2015).

\section{Application method and formulation}

The formulation and method by which a pesticide is applied influences treatment efficacy, as well as movement after application (Briggs et al., 2002; Derr, 1994). The active ingredient of a pesticide may be incorporated in different forms, such as granules, liquids, or emulsifiable concentrates, where components found within different formulations, including activators, solvents, and adjuvants, impart characteristics to the pesticide, thus influencing mobility in the environment (Wlodarczyk, 2014; Wlodarczyk and Siwek, 2016). Pesticides applied in solid forms will move as solids in water until dissolved, suspensions will move more freely but are typically insoluble, and dissolved pesticides will move freely in water unless adsorbed to soils or organic matter. However, soluble pesticides may not move as expected due to the properties of the pesticide. Isoxaben was present in runoff water at higher concentrations in the granular formulation compared to the sprayable formulation, most likely due to adsorption of the sprayable isoxaben following application, whereas the granules were dissolved with each irrigation application and with runoff before adsorption could occur (Briggs et al., 2002). Pesticides can be broadcast over the entirety of the production surface area, covering plants, containers, and interspace areas; applied to target locations, for example, postemergence herbicide applications; or incorporated as part of a container substrate mix (Graves et al., 2014). Agrochemicals applied as broadcast applications are more likely to be exported because they have fewer areas and opportunities for adsorption, whereas those applied to plants or in container substrates typically move through the substrate, where adsorption can occur, before being exposed to leaching events (Mahnken et al., 1999).

\section{Reducing pesticide movement}

Pesticides are subject to a range of degradation mechanisms based on the formulation, method of application, environmental conditions, and the site to which they are applied ( $\mathrm{Lu}$ et al., 2006). The breakdown of pesticides is critical to the prevention of excessive accumulation of persistent compounds in the environment (Arbeli and Fuentes, 2007). Degradation of pesticides occurs through chemical and biological processes and is influenced by site-specific conditions and environmental factors. Pesticides applied to nursery production sites are expected to adsorb to surfaces/soils or dissolve in water based on measured partition coefficients and solubility. Pesticides at the ground surface and in ponds are subject to photolysis (the breakdown of pesticides in response to sunlight), which is the primary degradation pathway for certain pesticides, such as the insecticide pirimicarb and the herbicide oxyfluorfen (Mantzos et al., 2014; Pirisi et al., 1996). The photodecomposition of pesticides occurs in either a direct or an indirect manner, with the former resulting from the compound reaching a photo-excited state, and the latter in response to reactions driven by light-induced reactive oxygen species present in water (Katagi, 2018). Pesticides may degrade in water via hydrolysis (Linde, 1994) or, based on the Henry's Law constant of a given compound, may volatilize, which is a physico-chemical process that results when a compound enters a gaseous state through either evaporation from water or sublimation from a solid form (Bedos et al., 2002).

\section{Biological degradation}

Microbially mediated degradation is a major pathway in the breakdown of certain pesticides, and it is considered a cost-effective, environmentally friendly treatment method for removing contaminants (Camper et al., 2001; Cycoń et al., 2011; Zhang et al., 2018). The degradation of pesticides by microbial communities may yield small organic molecules, such as carbon dioxide and water, or metabolites with properties that may differ from the parent compound (Huang et al., 2018; Ricking and Schwarzbauer, 2012). Pesticide breakdown occurs through a range of enzymatic reactions, such as oxidoreductases, monooxygenases, dioxygenases, $\mathrm{P} 450$ oxidoreductases, hydrolases, lyases, and dehalogenases (Coats, 1991; Sharma et al., 2016). Site-specific conditions modify the degradation process, with temperature, soil texture, soil moisture, and access to carbon and nutrient sources influencing microbial degradation (Javaid et al., 2016; Kumar et al., 2018; Ortiz-Hernandez et al., 2013) The amount of a particular pesticide available to surrounding microbial communities also influences the rate at which degradation occurs, with lower quantities potentially limiting the breakdown processes (Cederlund et al., 2016). Metabolites generated with the degradation of pesticides may be deleterious to water resources (Reemtsma et al., 2013) and may modify surrounding microbial communities (Mauffret et al., 2017). The organophosphate insecticide chlorpyrifos degrades via microbially mediated processes as well as hydrolysis; however, accumulation of the intermediate product trichloropyridinol occurs (Racke et al., 1990); upon breakdown, this releases free chlorine, which acts as a sanitizer inhibiting further degradation (Singh and Walker, 2006). The herbicide glyphosate has the tendency to bind to soils, which when detached via erosive water movement may be transported downstream and/or dissolve, allowing accumulation in stream sediments and receiving water bodies (Spengler et al., 2018). Microbial species are capable of using glyphosate as a phosphorus source (Hove-Jensen et al., 
2014), and converting it to metabolites such as aminomethylphosphonic acid (Yael et al., 2014), which is a compound that is more recalcitrant to degradation and more toxic than glyphosate itself (Ndjeri et al., 2013). The capacity for microbial communities to degrade pesticides is critical to their survival when facing contaminant pressure; ideally, the targeted biological processes convert a pesticide into a less toxic form, and that ideal end product is carbon dioxide and water (Mohan and Naveena, 2015; Parte et al., 2017).

\section{Conclusions}

Frequent irrigation and pesticide use are typical components in the production of container nursery crops. Water is the main mechanism of pesticide movement after application. Time is a critical factor in reducing pesticide movement that allows adsorption and degradative processes to occur. Practices that reduce the amount of water applied and delay irrigation after pesticide application can reduce pesticide movement. Irrigation practices that generate substantial volumes of runoff may export deleterious amounts of pesticides from production areas. Management practices that irrigate based on crop water use can reduce the volume of irrigation water applied, as well as the amount of runoff water generated. Pesticide movement varies between (and within) chemical classes, with environmental conditions, nursery infrastructure/layout, and other factors further influencing pesticide mobility. When possible, the selection of compounds or formulations with characteristics that limit mobility, such as low solubility and high-adsorption coefficients, may be an effective operational tool that can be used to limit pesticide movement in the nursery.

\section{Literature cited}

Agro, E. and Y. Zheng. 2014. Application rates for container nursery crop production in southwestern Ontario, Canada. HortScience 49:1414-1423.

Arbeli, Z. and C.L. Fuentes. 2007. Accelerated biodegradation of pesticides: An overview of the phenomenon, its basis and possible solutions; and a discussion on the tropical dimension. Crop Prot. 26:17331746.
Bayer, A., J. Ruter, and M.W. van Iersel. 2015. Automated irrigation control for improved growth and quality of Gardenia jasminoides 'Radicans' and 'August Beauty'. HortScience 50:78-84.

Bedos, C., P. Cellier, R. Calvet, E. Barriuso, and B. Gabrielle. 2002. Mass transfer of pesticides into the atmosphere by volatilization from soils and plants: Overview. Agronomie 22:21-33.

Beeson, R.C. Jr. and G.W. Knox. 1991. Analysis of efficiency of overhead irrigation in container production. HortScience 26:848-850.

Boithias, L., S. Sauvage, G. Merlina, S. Jean, J.L. Probst, and J.M.S. Perez. 2014. New insight into pesticide partition coefficient Kd for modelling pesticide fluvial transport: Application to an agricultural catchment in south-western France. Chemosphere 99:134-142.

Bolques, A., G. Knox, M. Chappell, L. Landrum, and E. Duke. 2011. Components of sustainable production practices for container plant nurseries. Proc. Florida State Hort. Soc. 124:294-298.

Briggs, J.A., M.B. Riley, and T. Whitwell. 1998. Quantification and remediation of pesticides in runoff water from containerized plant production. J. Environ. Qual. 27:814-820.

Briggs, J.A., T. Whitwell, R.T. Fernandez, and M.B. Riley. 2002. Formulation effects on isoxaben and trifluralin in runoff water from container plant nurseries. Weed Sci. 50:536-541.

Briggs, J.A., T. Whitwell, and M.B. Riley. 2003. Effect of delayed irrigation on isoxaben and oryzalin runoff from a container nursery. Weed Sci. 51:463-470.

Camper, N.D., J.H. Kim, and M.B. Riley. 2001. Degradation of isoxaben in soils and an aqueous system. J. Environ. Sci. Health 36:729-739.

Cederlund, H., E. Börjesson, D. Lundberg, and J. Stenström. 2016. Adsorption of pesticides with different chemical properties to a wood biochar treated with heat and iron. Water Air Soil Pollut. 227:203.

Chappell, M., J. Owen, S. White, and J.D. Lea-Cox. 2013. Irrigation management practices. In: T.H. Yeager, T. Bilderback, D. Fare, C. Gilliam, J. Lea-Cox, A. Niemiera, J. Ruter, K. Tilt, S. Warren, T. Whitwell, and R. Wright (eds.). Best management practices: Guide for producing nursery crops. 3rd ed. 27 Mar. 2019. <http://contents. sna.org/bmpv30.html>.

Coats, J.R. 1991. Pesticide degradation mechanisms and environmental activa- tion. Pesticide Transformation Prod. 459(2):10-30.

Cycoń, M., M. Wójcik, and Z. Piotrowska-Seget. 2011. Biodegradation kinetics of the benzimidazole fungicide thiophanate-methyl by bacteria isolated from loamy sand soil. Biodegradation 22:573-583.

Davies, M., R. Harrison-Murray, and C.J. Atkinson. 2016. Application of deficit irrigation to container-grown hardy ornamental nursery stock via overhead irrigation, compared to drip irrigation. Agr. Water Mgt. 163:244-254.

Dennis, J.H., R.G. Lopez, B.K. Behe, C.R. Hall, C. Yue, and B.L. Campbell. 2010. Sustainable production practices adopted by greenhouse and nursery plant growers. HortScience 45:1232-1237.

Derr, J.F. 1994. Innovative herbicide application methods and their potential for use in the nursery and landscape industries. HortTechnology 4:345-350.

Dion, H.M., J.B. Harsh, and H.H. Hill, Jr. 2001. Competitive sorption between glyphosate and inorganic phosphate on clay minerals and low organic matter soils. J. Radioanal. Nucl. Chem. 249:385390.

Fulcher, A. and R.T. Fernandez. 2013a. Sustainable nursery irrigation management series. Univ. Tennessee Ext. W279. 13-0098:1-7.

Fulcher, A. and T. Fernandez. 2013b. Sustainable nursery irrigation management series. Univ. Tennessee Ext. W280. 13-0098:1-5.

Fulcher, A., A.V. Lebude, J.S. Owen, Jr., S.A. White, and R.C. Beeson. 2016. The next ten years: Strategic vision of water resources for nursery producers. HortTechnology 26:121-132.

Graves, G.M., J.R. Vogel, J.B. Belden, E.J. Rebek, and A.M. Simpson. 2014. Investigation of insecticide leaching from potted nursery stock and aquatic health benefits of bioretention cells receiving nursery runoff. Environ. Sci. Pollut. Res. 21:8801-8811.

Grant, G.A., P.R. Fisher, J.E. Barrett, and P.C. Wilson. 2019. Removal of agrochemicals from water using granular activated carbon filtration. Water Air Soil Pollut. 230(7):1-12.

Hanson, B., C. Bond, K. Buhl, and D. Stone. 2015. Pesticide half-life fact sheet. 31 Jan. 2019. <http://npic.orst.edu/ factsheets/half-life.html>.

Hoskins, T.C., J.S. Owen, Jr., and A.X. Niemiera. 2014. Water movement through a pine-bark substrate during irrigation. HortScience 49:1432-1436. 
Hove-Jensen, B., D.L. Zechel, and B. Jochimsen. 2014. Utilization of glyphosate as phosphate source: Biochemistry and genetics of bacterial carbon-phosphorus lyase. Microbiol. Mol. Biol. Rev. 78:176-197.

Huang, Y., L. Xiao, F. Li, M. Xiao, D. Lin, X. Long, and Z. Wu. 2018. Microbial degradation of pesticide residues and an emphasis on the degradation of cypermethrin and 3-phenoxy benzoic acid: A review. Molecules 23(9):1-23.

Javaid, M.K., M. Ashiq, and M. Tahir. 2016. Potential of biological agents in decontamination of agricultural soil. Scientifica 2016:1-9.

Karam, N.S. and A.X. Niemiera. 1994. Cyclic sprinkler irrigation and pre-irrigation substrate water content affect water and $\mathrm{N}$ leaching from containers. J. Environ. Hort. 12:198-202.

Katagi, T. 2018. Direct photolysis mechanism of pesticides in water. J. Pestic. Sci. 43(2):1-16.

Kumar, S., G. Kaushik, M.A. Dar, S. Nimesh, U.J. López-Chuken, and J.F. Villarreal-Chiu. 2018. Microbial degradation of organophosphate pesticides: A review. Pedosphere 28:190-208.

Langeron, J., A. Blondel, S. Sayen, E. Hénon, M. Couderchet, and E. Guillon. 2014. Molecular properties affecting the adsorption coefficient of pesticides from various chemical families. Environ. Sci. Pollut. Res. 21:9727-9741.

Lao, W.J., G. Arye, F. Ernst, Y.P. Xu, S. Bondarenko, D. Haver, J. Kabashima, and J. Gan. 2008. Reduction of pyrethroid runoff from a commercial nursery, p. 428-455. In: J. Gan, F. Spurlock, P. Hendley, and D.P. Weston (eds.). Synthetic pyrethroids: Occurrence and behavior in aquatic environments. Amer. Chem. Soc., Washington, DC.

Lea-Cox, J.D. and D.S. Ross. 2001. Clean water policy and the rationale for developing a water and nutrient management process for container nursery and greenhouse operations. J. Environ. Hort. 19:230-236.

Lea-Cox, J.D., W.L. Bauerle, M.W. van Iersel, G.F. Kantor, T.L. Bauerle, E. Licthenberg, D.M. King, and L. Crawford. 2013. Advancing wireless sensor networks for irrigation management of ornamental crops: An overview. HortTechnology 23:717-724.

Lee, H., W.J. Shim, and J.H. Kwon. 2014. Sorption capacity of plastic debris for hydrophobic organic chemicals. Sci. Total Environ. 470/471:15451552.
Lichtenberg, E., J. Majsztrik, and M. Saavoss. 2013. Profitability of sensorbased irrigation in greenhouse and nursery crops. HortTechnology 23:770-774.

Linde, C. 1994. Physio-chemical properties and environmental fate of pesticides. Environ. Hazards Assessment Program, State of California, Environ. Protection Agency, Dept. Pesticide Regulat., Environ. Monitoring Pest Mgt. Branch EH 94-03:1-53.

Lu, J., L. Wu, J. Newman, B. Faber, and J. Gan. 2006. Degradation of pesticides in nursery recycling pond waters. J. Agr. Food Chem. 54:2658-2663.

Mahnken, G.E., W.A. Skroch, R.B. Leidy, and T.J. Sheets. 1999. Metolachlor and simazine in surface runoff water from a simulated container plant nursery. Weed Technol. 13:799-806.

Majsztrik, J.C., A.G. Ristvey, and J.D. Lea-Cox. 2011. Water and nutrient management in the production of container-grown ornamentals. Hort. Rev. 38:253-297.

Majsztrik, J.C. and J.D. Lea-Cox. 2013. Water quality regulations in the Chesapeake Bay: Working to more precisely estimate nutrient loading rates and incentivize best management practices in the nursery and greenhouse industry. HortScience 48:1097-1102.

Majsztrik, J.C., R.T. Fernandez, P.R. Fisher, D.R. Hitchcock, J. Lea-Cox, J.S. Owen, Jr., L.R. Oki, and S.A. White. 2017. Water use and treatment in container-grown specialty crop production: A review. Water Air Soil Pollut. 228:151.

Mangiafico, S.S., J. Gan, L. Wu, J. Lu, J.P. Newman, B. Faber, D.J. Merhaut, and R. Evans. 2008. Detention and recycling basins for managing nutrient and pesticide runoff from nurseries. HortScience 43:393-398.

Mantzos, N., A. Karakitsou, D. Hela, G. Patakious, E. Leneti, and I. Konstantinou. 2014. Persistence of oxyfluorfen in soil, runoff water, sediment, and plants of a sunflower cultivation. Sci. Total Environ. 472:767-777.

Mathers, H.M., T.H. Yeager, and L.T. Case. 2005. Improving irrigation water use in container nurseries. Hort Technology 15:8-12.

Mauffret, A., N. Baran, and C. Joulian. 2017. Effect of pesticides and metabolites on groundwater bacterial community. Sci. Total Environ. 576:879-887.

Million, J., T. Yeager, H. Bryant, C. Larsen, J. Shook, and J. Albano. 2005. Effects of slope and underlay on surface runoff of irrigation from woven poly- propylene groundcloth. HortTechnology 15:772-776.

Million, J.B. and T.H. Yeager. 2015. Capture of sprinkler irrigation water by container-grown ornamental plants. HortScience 50:442-446.

Mohan, N. and L. Naveena. 2015. Isolation and determination of efficacy of acephate degrading bacteria from agricultural soil. J. Environ. Sci. Toxicol. Food Technol. 9(3):10-20.

Ndjeri, M., A. Pensel, S. Peulon, V. Haldys, B. Desmazières, and A. Chausse. 2013. Degradation of glyphosate and AMPA (aminomethylphosphonic acid) solutions by thin films of birnessite electrodeposited: A new design of material for remediation processes? Colloids Surf. A Physicochem. Eng. Asp. 435:154-169.

O'Connor, I., L. Goljstein, and A.J. Hendriks. 2016. Review of the partitioning of chemicals into different plastics: Consequences for the risk assessment of marine plastic debris. Mar. Pollut. Bull. 113(1-2):17-24.

Ortiz-Hernandez, M.L., E. Sanchez-Salinas, E. Dantan-Gonzalez, and M.L. Castrejon-Godinez. 2013. Pesticide biodegradation: Mechanisms, genetics and strategies to enhance the process, p. 261287. In: R. Chamy and F. Rosenkranz (eds.). Biodegradation-Life of science. InTech, Rijeka, Croatia.

Owen, J.S., Jr., A.V. Lebude, M. Chappell, and T. Hoskins. 2016. Advanced irrigation management for container-grown ornamental crop production. Virginia Coop. Ext. Hort 218-P:1-18.

Parte, S.G., A.D. Mohekar, and A.S. Kharat. 2017. Microbial degradation of pesticide: A review. Afr. J. Microbiol. Res. 11:992-1012.

Paudel, K.P., M. Pandit, and R. Hinson. 2016. Irrigation water sources and irrigation application methods used by U.S. plant nursery producers. Water Resour. Res. 52:698-712.

Pershey, N.A., B.M. Cregg, J.A. Andresen, and R.T. Fernandez. 2015. Irrigation based on daily water use reduces nursery runoff volume and nutrient load without reducing growth of four conifers. HortScience 50:1553-1561.

Pirisi, F.M., P. Cabras, L.V. Garau, M. Melis, and E. Secchi. 1996. Photodegradation of pesticide, photolysis rates, and half-life of pirimicarb and its metabolites in reactions in water and in solid phase. J. Agr. Food Chem. 44:24172422.

Pitton, B.J., C.R. Hall, D.L. Haver, S.A. White, and L.R. Oki. 2018. A cost analysis 
for using recycled irrigation runoff water in container nursery production: A southern California nursery case study. Irr. Sci. 36:217-226.

Racke, K.D., D.A. Laskowski, and M.R. Schultz. 1990. Resistance of chlorpyrifos to enhanced biodegradation in soil. J. Agr. Food Chem. 38:1430-1436.

Reemtsma, T., L. Alder, and U. Banasiak. 2013. Emerging pesticide metabolites in groundwater and surface water as determined by the application of a multimethod for 150 pesticide metabolites. Water Res. 47:5535-5545.

Ricking, M. and J. Schwarzbauer. 2012. DDT isomers and metabolites in the environment: An overview. Environ. Chem. Lett. 10:317-323.

Riley, M.B. 2003. Herbicide losses in runoff of containerized plant production nurseries. HortTechnology 13:16-22.

Ross, D.S., J.D. Lea-Cox, and K.M. Teffeau. 2001. The importance of water in the nutrient management process. Proc. Southern Nursery Assn. Res. Conf 46:588-591.

Sharma, A. P. Pankaj, S. Khati, Gangola, and G. Kumar. 2016. Microbial degradation of pesticides for environmental cleanup, p. 178-205. In: R.N. Bharagava and G. Saxena (eds.). Bioremediation of industrial pollutants. Write and Print Publ., New Delhi, India.

Shipitalo, M.J., J.V. Bonta, E.A. Dayton, and L.B. Owens. 2010. Impact of grassed waterways and compost filter socks on the quality of surface runoff from corn fields. J. Environ. Qual. 39:1009-1018.

Singh, B.K. and A. Walker. 2006. Microbial degradation of organophosphorus compounds. Federation European Microbiol. Soc. 30:428-471.

Spangler, J.T., D.J. Sample, L.J. Fox, J.S. Owen, Jr., and S.A. White. 2019. Floating treatment wetland aided nutrient removal from agricultural runoff using two wetland species. Ecol. Eng. 127:468-479.

Spengler, S.R., M.D. Heskett, and S.C. Spengler. 2018. Glyphosate in runoff from urban, mixed-use and agricultural watersheds in Hawaii, USA, p. 65-77. In: S. Hernández and S. Mambretti (eds.). Water Pollution XIV. WIT Press, Southampton, UK.

Suntio, L.R., W.Y. Shiu, D. Mackay, J.N. Seiber, and D. Glotfelty. 1988. Critical review of Henry's Law constants for pesticides. Rev. Environ. Contam. Toxicol. 103:1-59.

Taylor, A.J., R.T. Fernandez, P. Nzokou, and B. Cregg. 2013. Carbon isotope discrimination, gas exchange, and growth of container-grown conifers under cyclic irrigation. HortScience 48:848-854.

Warsaw, A.L., R.T. Fernandez, B.M. Cregg, and J.A. Andresen. 2009a. Water conservation, growth, and water use efficiency of container-grown woody ornamentals irrigated based on daily water use. HortScience 44:1308-1318.

Warsaw, A.L., R.T. Fernandez, B.M. Cregg, and J.A. Andresen. 2009b. Container-grown ornamental plant growth and water runoff nutrient content and volume under four irrigation treatments. HortScience 44:1573-1580.

Warsaw, A.L., R.T. Fernandez, D.R. Kort, B.M. Cregg, B. Rowe, and C. Vandervoort. 2012. Remediation of metalaxyl, trifluralin, and nitrate from nursery runoff using container-grown woody ornamentals and phytor- emediation areas. Ecol. Eng. 47:254263.

Weatherspoon, D.M. and C.C. Harrell. 1980. Evaluation of drip irrigation for container production of woody landscape plants. HortScience 15:488-489.

Wilson, P.C., T. Whitwell, and M.B. Riley. 1995. Effects of ground cover and formulation on herbicides in runoff water from miniature nursery sites. Weed Sci. 43:671-677.

Wilson, C., T. Whitwell, and M.B. Riley. 1996. Detection and dissipation of isoxaben and trifluralin in containerized plant nursery runoff water. Weed Sci. 44:683-688.

Wlodarczyk, M. 2014. Influence of formulation on mobility of metazachlor in soil. Environ. Monit. Assess. 186:35033509.

Wlodarczyk, M. and H. Siwek. 2016. Influence of formulation on mobility of clomazone in soil. Bull. Environ. Contam. Toxicol. 97:582-587.

Yael, J.A., J.D. Fuhr, G.A. Bocan, A.D. Millone, N. Tognalli, M. dos Santos Alfonso, and M.L. Martiarena. 2014. Abiotic degradation of glyphosate into aminomethylphosphonic acid in the presence of metals. J. Agr. Food Chem. 62:9651-9656.

Zhang, Q., S. Li, C. Ma, N. Wu, C. Li, and X. Yang. 2018. Simultaneous biodegradation of bifenthrin and chloryprifos by Pseudomonas sp. CB2. J. Environ. Sci. Health 53:304-312. 